\title{
Persepsi Petani tentang Kompetensi Keujruen Blang di Kabupaten Aceh Besar Provinsi Aceh
}

\section{Farmer Perceptions of Keujruen Blang competence in Aceh Besar Regency, Aceh Province}

\author{
Ikhsan $^{1}$, Pudji Muljono ${ }^{2}$, Dwi Sadono ${ }^{2}$ \\ ${ }^{1}$ Program Studi Pascasarjana Ilmu Penyuluhan Pembangunan, Fakultas Ekologi Manusia, \\ Institut Pertanian Bogor, Bogor \\ ${ }^{2}$ Departemen Sains Komunikasi dan Pengembangan Masyarakat, Fakultas Ekologi Manusia, Institut Pertanian Bogor, Bogor
}

\begin{abstract}
Keujruen blang is a traditional institution of agriculture to help farmers with the management of paddy fields, community development, and problem solutions in farming activities. This study was aimed to (1) analyze the level of farmers' knowledge about farming and perception of competence in agricultural development, (2) to analyze the correlation between characteristics of farmers and extension activities with farming knowledge. This study used a survey method and was conducted from June to July 2017 in 10 selected Districts of Aceh Besar Regency. Statistical descriptions and inferential statistics (Spearman rank) were taken as an analytical method. The results showed that (1) the level of keujruen blang competence is in the high category. This can be seen from the following activities: how to go to the rice fields, water distribution, coordination with the government, coordination of khanduri blang, and the provision of reprimands and sanctions, and (2) factors that are significantly related to farmers perceptions of the competence in agriculture development are farmer characteristics (farming experience, and income level) and extension activities (intensity, material appropriateness, extension media suitability and extension methods).
\end{abstract}

Keywords : competence, extension, farmers, keujruen blang, perceptions,

\begin{abstract}
Abstrak
Keujruen blang adalah lembaga adat yang bergerak di bidang pertanian untuk membantu persoalan petani dalam pengelolaan kawasan persawahan, pembinaan masyarakat, pembangunan dan penyelesaian masalah-masalah dalam penyelenggaraan usaha pertanian. Penelitian ini bertujuan untuk: (1) menganalisis tingkat persepsi petani tentang kompetensi keujruen blang dalam pengembangan pertanian, (2) menganalisis hubungan karakteristik petani dan kegiatan penyuluhan dengan tingkat persepsi petani tentang kompetensi keujruen blang dalam pengembangan pertanian. Penelitian ini menggunakan metode survei dan dilaksanakan pada bulan Juni dan Juli 2017 di 10 kecamatan di Kabupaten Aceh Besar Provinsi Aceh. Metode analisis yang digunakan adalah statistik deskriptif dan inferensial (rank Spearman). Hasil penelitian menunjukkan bahwa: (1) tingkat kompetensi keujruen blang berada pada kategori tinggi. Hal tersebut dilihat dari: tata cara turun ke sawah, pengaturan pembagian air, koordinasi dengan pemerintah, mengkoordinasikan khanduri blang, dan pemberian teguran dan sanksi. (2) faktor yang berhubungan nyata dengan tingkat persepsi petani tentang kompetensi keujruen blang dalam pengembangan pertanian adalah karakteristik petani (pengalaman usahatani, dan tingkat pendapatan) dan kegiatan penyuluhan (intensitas mengikuti penyuluhan, kesesuaian materi penyuluhan, kesesuaian media penyuluhan dan ketepatan metode penyuluhan).
\end{abstract}

Kata kunci: keujruen blang, kompetensi, penyuluhan, persepsi, petani

\section{Pendahuluan}

Air merupakan substansi terpenting dalam usahatani padi sawah. Air harus selalu tersedia selama usahatani itu berlangsung. Pengelolaan air dibutuhkan untuk menjaga ketersedian air. Petani membutuhkan bantuan pihak ketiga yang mampu melakukan pengelolaan air secara maksimal. Keujruen blang merupakan lembaga yang berfungsi untuk mengoordinasikan masyarakat tani mulai dari sektor pertanian hingga sektor sosial (adat istiadat) masyarakat Aceh. Oleh karena itu, posisi

${ }^{1}$ Korespondensi penulis

E-mail: ikhsanmuhammad176@gmail.com keujruen blang dianggap sangat penting dalam tatanan masyarakat Aceh.

Berbagai program dicanangkan oleh pemerintah untuk meningkatkan kemakmuran masyarakat tani dengan adanya dukungan terhadap keujruen blang yang diperkuat dengan dikeluarkannya dua hukum setingkat Peraturan Daerah (PERDA) yang disebut dengan qanun yaitu peraturan yang mengatur secara lebih rinci tentang peranan adat serta fungsi lembaga adat dalam masyarakat Aceh, utamanya yang diformulasikan 
dalam Qanun nomor 9 tahun 2008 tentang pembinaan kehidupan adat dan adat istiadat serta Qanun nomor 10 tahun 2008 tentang lembaga adat keujruen blang. Kedua qanun tersebut menjabarkan tentang berbagai aturan dasar yang berhubungan dengan bagaimana adat difungsikan kembali dalam kehidupan sosial masyarakat tani. Menurut Putra et al. (2016) ada tiga hal utama yang ditekankan dalam Qanun nomor 9 dan 10 tahun 2008 yaitu: (1) pelestarian adat yang bersifat kultural dalam masyarakat, (2) pemungsian kembali peradilan adat dan (3) membangun kembali lembaga adat dalam masyarakat.

Qanun Aceh nomor 10 tahun 2008 menegaskan bahwa pembangunan lembaga adat ditujukan sebesar-besarnya untuk memakmurkan masyarakat tani serta mengatur seluruh kepentingannya secara adat. Keujruen blang merupakan kelembagaan lokal terkait dengan pelaksanaan pembangunan pertanian, membina nilai-nilai budaya, norma-norma adat serta aturan untuk mewujudkan keamanan, kerukunan, ketertiban dan kesejahteraan bagi masyarakat tani. Menurut pasal 25 Qanun nomor 10 Tahun 2008 menyatakan bahwa keujruen blang mempunyai tugas yaitu: (1) menentukan dan mengkoordinasikan tata cara turun ke sawah, (2) mengatur pembagian air ke sawah petani, (3) membantu pemerintah dalam bidang pertanian, (4) mengkoordinasikan khanduri blang atau upacara lain yang berkaitan dengan adat usaha pertanian, (5) memberi teguran dan sanksi kepada petani yang melanggar aturan-aturan adat meugoe (bersawah) atau tidak melaksanakan kewajiban lain dalam sistem pelaksanaan pertanian sawah secara adat, (6) menyelesaikan sengketa antar petani yang berkaitan dengan pelaksanaan usaha pertanian sawah.

Masalah utama di daerah penelitian adalah perebutan air antara petani sehingga menyebabkan kekurangan air di wilayah tertentu dan adanya musim kemarau yang berkepanjangan sehingga menyebabkan kelangkaan air. Dalam jangka panjang kekurangan dan kelangkaan air mengakibatkan terkendalanya proses produksi pertanian sehingga kebutuhan air sangat tergantung dari musim hujan. Adanya pembangunan Jaringan Irigasi Air Tanah (JIAT) dan pembangunan 17 unit sumur bor yang menjadi sumber air untuk kawasan tadah hujan oleh Pemerintah Kabupaten Aceh Besar (Pemkab) sangat mendukung ketersedian air untuk usahatani padi sawah. Pada kawasan tadah hujan, keberlangsungan pengelolaan irigasi akan sangat dipengaruhi oleh kemampuan keujruen blang dalam memaksimalkan pengelolaan air irigasi sehingga diperlukan kompetensi tertentu dari keujruen blang dalam pengelolaan air irigasi diatur secara optimal mungkin. Atas dasar itu, bagaimana keujruen blang memiliki kompetensi tersebut dapat ditelusuri dari persepsi masyarakat terhadap kemampuan keujruen blang.

Masyarakat tani meyakini bahwa ketersedian air irigasi berfungsi untuk mendukung produktivitas lahan pertanian melalui pengaturan tata kelola air, sehingga menjamin pemberian air secara optimal dan merata oleh keujruen blang baik pada musim kemarau maupun pada musim hujan. Pemerintah daerah mengatur ketersediaan air dalam Qanun nomor 10 Pasal 25 tahun 2008 dan dengan melakukan pembangunan 17 unit sumur bor, pembangunan jaringan irigasi air tanah (JIAT).

Selanjutnya dalam Qanun Aceh nomor 4 tahun 2011 dijelaskan tujuan dan fungsi irigasi yang bertujuan untuk mengoptimalkan pemanfaatan air irigasi untuk kepentingan di bidang pertanian dalam rangka mewujudkan ketahanan pangan Aceh dan nasional, kesejahteraan masyarakat tani dan kepentingan lainnya sesuai dengan peraturan perundang-undangan. Hasil penelitian Yulia et al. (2012) bahwa fungsi dan kewenangan keujruen blang yang berjalan sekarang masih berdasarkan pengalaman belum mengenal fungsinya secara detail termasuk yang terdapat dalam qanun. Bahkan fungsi keujruen blang dipahami hanya sebatas menjaga dan pembagian air sawah.

Mengingat pentingnya pengembangan kompetensi keujruen blang, diperlukan informasi yang faktual tentang bagaimana realita dan harapan terhadap kompetensi keujruen blang, serta petani sebagai objek partisipan dianggap mengetahui kompetensi keujruen blang tersebut. Berdasarkan uraian di atas, perlu diteliti persepsi petani tentang kompetensi keujruen blang di Kabupaten Aceh Besar Provinsi Aceh. Tujuan penelitian ini adalah: (1) menganalisis tingkat persepsi petani tentang kompetensi keujruen blang dalam pengembangan pertanian, (2) menganalisis hubungan karakteristik petani dan kegiatan penyuluhan dengan tingkat persepsi petani tentang kompetensi keujruen blang dalam pengembangan pertanian. 


\section{Metode Penelitian}

Penelitian ini menggunakan metode survei dengan analisis statistik deskriptif dan inferensial menggunakan analisis rank Spearman yang dilengkapi dengan data kualitatif. Lokasi penelitian berada pada 10 kecamatan di Kabupaten Aceh Besar Provinsi Aceh. Pengambilan data lapangan pada bulan Juni hingga Juli 2017. Populasi penelitian adalah petani padi sawah yang berada di wilayah lembaga adat keujruen blang yang terpilih di Kabupaten Aceh Besar Provinsi Aceh.

Pengambilan sampel dari setiap kecamatan diambil dua desa, dari setiap desa diambil 1 kelompok tani. Dari masing-masing kelompok tani terpilih diambil 5 orang, yang terdiri dari 2 pengurus keujruen muda dan 3 anggota kelompok tani, yang diambil secara Random Sampling di desa terpilih, sehingga sampel dalam penelitian ini berjumlah 100 responden. Uji validitas dan reliabilitas dilakukan pada 30 orang non sampel di Desa Batee Linteung Kecamatan Simpang Tiga Kabupaten Aceh Besar Provinsi Aceh. Hasil uji validitas nilai $r$ hitungnya berkisar antara $-0,418$ hingga 0,472, sedangkan hasil uji reliabilitas nilai cronbach's alphanya berkisar antara 0,724 hingga 0,765 .

Pengujian hipotesis dalam penelitian ini menggunakan uji korelasi rank Spearman yang bertujuan untuk melihat hubungan antar variabel. Nilai koefisien yang digunakan adalah hasil dari uji rank Spearman dengan menggunakan perangkat lunak SPSS (Statistical Package for the Social Science) versi 22.

\section{Hasil dan Pembahasan}

Pembangunan pertanian khususnya untuk pengembangan komoditas padi sawah dilakukan melalui dinas pertanian yang bekerja sama dengan Badan Pelaksana Penyuluhan Kabupaten Aceh Besar sebagai upaya peningkatan produktifitas tanaman padi sawah dengan dilakukannya berbagai penyuluhan untuk menambah pengetahuan keterampilan dan sikap petani terhadap proses adopsi suatu inovasi dalam mengelola usahataninya. Maka perlu didukung oleh para agen perubahan yakni penyuluh, khususnya keujruen blang (penyuluh swadaya) yang dapat menjadi partner bagi penyuluh PNS dengan dasar bahwa penyuluh swadaya adalah orang yang dekat dengan petani karena kebanyakan dari mereka adalah ketua lembaga adat keujruen blang, ketua kelompok tani, dan ketua gapoktan yang artinya mereka memiliki pengaruh bagi petani lain karena adanya rasa percaya yang ditanamkan oleh petani kepada penyuluh swadaya (keujruen blang).

Penyuluh swadaya (keujruen blang) yang ada di setiap kecamatan merupakan warga setempat, sehingga ketika penyuluh swadaya hendak melakukan penyuluhan mereka cukup menggunakan kendaraan beroda dua untuk sampai di tempat pertemuan maupun ke rumah petani. Ada juga penyuluh swadaya yang berjalan kaki karena jarak tempuh ke tempat petani yang dibina cukup dekat.

\section{Karakteristik Petani}

Karakteristik individu dalam penelitian ini mencakup sosio-demografi yang merupakan ciri yang melekat pada individu meliputi umur, tingkat pendidikan formal,jumlah tanggungan keluarga, mata pencaharian, luas lahan garapan, pengalaman usahatani, dan tingkat kekosmopolitan. Sebaran responden berdasarkan karakteristik petani padi sawah disajikan pada Tabel 1.

\section{a) Umur}

Umur petani dalam penelitian ini sebagian besar berada pada kategori dewasa $(64,00$ persen) dengan rataan umur 45 tahun (Tabel 1). Berdasarkan kelompok umur tersebut, maka dapat diartikan bahwa secara fisik petani memiliki potensi atau kemampuan untuk bekerja melakukan usahatani padi sawahnya sesuai dengan keterampilan dan pengalaman dalam mengelola sumber daya pertanian yang mereka miliki. Hal ini menunjukkan bahwa Kabupaten Aceh Besar memiliki aset sumberdaya manusia yang potensial untuk ditingkatkan dan dikembangkan kemampuannya dalam upaya pengelolaan pertanian. Hal ini sejalan dengan hasil penelitian Suherdi (2014) bahwa dalam aktivitas berusahatani petani yang berada pada usia sangat produktif memiliki fisik yang kuat, pengetahuan dan kemampuan yang cukup dan hubungan sosial yang baik, sehingga berpotensi mampu melakukan usahatani dengan baik untuk dapat memperoleh hasil produksi yang optimal. Ehrenberg dan Smith (1988) menemukan bahwa umur berpengaruh langsung terhadap produktivitas tenaga kerja. Semakin bertambah umur seseorang maka tenaga yang dimiliki 
Tabel 1. Jumlah dan Persentase Petani berdasarkan Kategori Karakteristik Petani di Kabupaten Aceh Besar pada Tahun 2017

\begin{tabular}{llcc}
\hline \multicolumn{1}{c}{ Karakteristik petani } & \multicolumn{1}{c}{ Kategori } & Jumlah (orang) & Persentase (\%) \\
\hline Umur & Muda (15-35) & 17 & 17,00 \\
Rataan $=45$ & Dewasa (36-50) & 64 & 64,00 \\
& Tua (51-70) & 19 & 19,00 \\
Tingkat pendidikan formal & Rendah (TS-SD) & 11 & 11,00 \\
Rataan = sedang & Sedang (SMP-SMA) & 84 & 84,00 \\
& Tinggi (Perguruan Tinggi) & 5 & 5,00 \\
Jumlah Tanggungan Keluarga & Sedikit (1-3) & 59 & 59,00 \\
Rataan=3 & Sedang (4-6) & 37 & 37,00 \\
& Banyak (>7) & 4 & 4,00 \\
Luas Lahan Garapan & Sempit (<1 ha) & 91 & 91,00 \\
Rataan=0,73 & Sedang (1.1-2 ha) & 9 & 9,00 \\
Pengalaman Usahatani & Luas (>2 ha) & 0 & 0,00 \\
Rataan=19 & Baru (0-15) & 47 & 47,00 \\
& Sedang (16-30) & 39 & 39,00 \\
Tingkat Kekosmopolitan & Lama (>31) & 14 & 14,00 \\
Rataan=5 & Rendah (0-2) & 12 & 12,00 \\
& Sedang (3-4) & 40 & 40,00 \\
& Tinggi (>5) & 48 & 48,00 \\
\hline
\end{tabular}

semakin produktif dan setelah pada batas umur tertentu produktifitasnya semakin menurun.

\section{b) Tingkat Pendidikan Formal}

Tingkat pendidikan formal responden dalam penelitian ini berada pada kategori rendah mulai dari tidak bersekolah hingga menamatkan SD, sementara tingkat pendidikan formal yang tergolong tinggi mencapai perguruan tinggi yaitu Strata 1 (S-1). Hasil penelitian menunjukkan bahwa tingkat pendidikan formal responden sebagian besar berada pada kategori sedang (84,00 persen). Hal tersebut disebabkan tingginya kesadaran internal serta peran orang tua menyekolahkan anaknya hingga ke jenjang yang lebih tinggi. Sebagian besar responden berpendapat bahwa dengan keadaan demikian lebih memilih berusaha keras menempuh pendidikan sejak umur sangat muda dan tidak menyia-nyiakan bakat atau potensi yang dimilikinya untuk membantu perekonomian keluarga di masa mendatang. Hal ini sejalan dengan penelitian Hartati et al. (2005) bahwa salah satu cara yang dapat ditempuh untuk meningkatkan sumberdaya manusia melalui upaya peningkatan minat anak dan orang tua untuk melanjutkan pendidikan ke jenjang yang lebih baik.

\section{c) Jumlah Tanggungan Keluarga}

Jumlah tanggungan keluarga dapat memberikan sumbangan yang besar terhadap ketersediaan tenaga kerja, namun di sisi lain dapat menyebabkan tingginya beban perekonomian keluarga. Jumlah tanggungan keluarga dalam penelitian ini berkisar antara 1 hingga 9 orang. Jumlah tanggungan keluarga responden terbesar berada kategori sedikit cenderung sedang dengan rataan sebanyak 3 orang. Kenyataan di lapangan menunjukkan bahwa sebagian dari responden masih memiliki tanggungan dalam usia belum produktif (usia sekolah) sehingga memerlukan biaya dan belum dapat membantu dalam kegiatan usahatani padi sawah. Hal ini akan sangat mempengaruhi terhadap kemampuas responden dalam melakukan usahanya serta kemampuan untuk meningkatkan pendapatanya.

\section{d) Luas Lahan Garapan}

Berdasarkan hasil penelitian diketahui bahwa kisaran 
luas lahan responden berkisar antara 0.25 hektar hingga 3 hektar. Persentase terbesar adalah berada pada kategori sempit (91,00 persen) yang luasnya hanya berkisar antara 0.25 hektar hingga 1 hektar. Hal tersebut menunjukkan bahwa petani perlu adanya manajemen pengolahan lahan yang memungkinkan tercapainya skala usaha. Hal ini sejalan dengan penelitian Sutiyah (1990) yang menemukan bahwa petani yang memiliki lahan yang luas biasanya mempekerjakan orang lain untuk melakukan pengolahan tanah, penanaman, pemeliharaan, panen dan lain sebagainya, petani hanya datang sewaktu-waktu untuk mengecek pekerjaan yang dilakukan oleh pekerjanya, sehingga petani tidak terkendala dengan kecilnya jumlah tanggungan keluarga yang dimiliki dalam mengelola tanaman padi sawah.

\section{e) Pengalaman Berusahatani}

Pengalaman berusahatani dalam penelitian ini berada pada kategori baru cenderung sedang dengan rataan 19 tahun. Hal tersebut menunjukkan bahwa petani yang pengalaman usahataninya lebih lama memiliki kemampuan dalam berusahatani lebih baik. Kondisi ini dikarenakan pengalaman yang lebih banyak sehingga sudah dapat membuat perbandingan dalam mengambil keputusan. Hal ini sejalan dengan pendapat Mardikanto (1993) bahwa pengalaman usahatani yang dimiliki seseorang akan mempengaruhi proses pengambilan keputusan, sehingga petani yang memiliki pengalaman usahatani lebih lama cenderung akan selektif dalam proses pengambilan keputusan dibandingkan dengan petani yang memiliki pengalaman yang sedikit.

\section{f) Tingkat Kekosmopolitan}

Tingkat kekosmopolitan dalam penelitian ini berada pada kategori tinggi cenderung sedang dengan rataan 5. Hal tersebut menunjukkan bahwa petani sering bepergian keluar desa mencari informasi tentang usahatani padi sawah seperti mengunjungi dinas pertanian, lembaga adat keujruen blang, dan mudah menerimaide-idebaru. Kondisi ini menunjukkan bahwa petani sering menjumpai keujruen blang kecamatan di sawah atau warung kopi untuk memperoleh informasi seputar usahatani misalnya kapan waktu yang tepat turun ke sawah dan penyaluran air. Peranan keujruen blang dalam suatu kegiatan lembaga adat sangat berperan penting sebagai jembatan penghubung antara pemerintah serta menyampaikan umpan balik dari masyarakat tani yang bertujuan membantu masyarakat tani memperbaiki mutu hidup dan kesejahteraan keluarganya.

\section{Kegiatan Penyuluhan}

Kegiatan penyuluhan yang diteliti terdiri dari intensitas mengikuti penyuluhan, kesesuaian materi penyuluhan, kesesuaian media penyuluhan dan ketepatan metode penyuluhan. Berdasarkan hasil penelitian kegiatan penyuluhan terhadap tingkat pengetahuan petani tentang usahatani secara umum termasuk kategori

Tabel 2. Jumlah dan Persentase Petani berdasarkan Kategori Kegiatan Penyuluhan di Kabupaten Aceh Besar pada Tahun 2017

\begin{tabular}{llcc}
\hline \multicolumn{1}{c}{ Kegiatan Penyuluhan } & \multicolumn{1}{c}{ Kategori } & Jumlah (Orang) & Persentase (\%) \\
\hline Intensitas Mengikuti Penyuluhan & Rendah (0-2) & 56 & 56,00 \\
Rataan=2 & Sedang (3-4) & 29 & 29,00 \\
& Tinggi (>5) & 15 & 15,00 \\
Kesesuaian Materi Penyuluhan & Kurang Sesuai (1-10) & 2 & 2,00 \\
Rataan=23 & Cukup Sesuai (11-20) & 14 & 14,00 \\
& Sangat Sesuai (21-30) & 84 & 84,00 \\
Kesesuaian Media Penyuluhan & Kurang Sesuai (1-5) & 18 & 18,00 \\
Rataan=13 & Cukup Sesuai (6-10) & 1 & 1,00 \\
& Sangat Sesuai (11-15) & 81 & 81,00 \\
Ketepatan Metode Penyuluhan & Kurang Tepat (1-6) & 56 & 56,00 \\
Rataan $=12$ & Tepat (7-12) & 4 & 4,00 \\
& Sangat Tepat (13-18) & 40 & 40,00 \\
\hline
\end{tabular}


sedang dan tinggi. Secara rinci hasil penelitian disajikan pada Tabel 2.

\section{a) Intensitas Mengikuti Penyuluhan}

Intensitas mengikuti penyuluhan dalam penelitian ini berada pada kategori rendah cenderung sedang. Intensitas mengikutui penyuluh digambarkan oleh tingkat kunjungan dan kehadiran responden dalam mengikuti kegiatan penyuluhan yang diadakan di kantor Unit Pelaksana Teknik Daerah (UPTD). Relatif rendahnya kegiatan penyuluhan yang diikuti responden disebabkan kegiatan penyuluhan sering diadakan di satu lokasi dalam satu mukim (wilayah kemukiman) yang menggabungkan lebih dari dua desa serta jarak tempuh antar desa ke tempat penyuluhan sangat jauh. Penyuluh harus menyesuaikan lokasi penyuluhannya agar petani tersebut dapat ikut serta dalam setiap kegiatan penyuluhan tentang usahatani padi sawah. Jumlah kegiatan penyuluhan dalam tiga bulan berkisar 1-3 kali, penyuluh perlu meningkatkan kegiatan penyuluhan untuk membantu responden menghadapi permasalahan selama usahatani. Di lokasi penelitian setiap kecamatan 1 orang penyuluh melayani dua desa. Penyuluh pertanian melaksanakan kegiatan kunjungan berdasarkan rencana kerja tahunan yang telah disusun dalam buku programa penyuluhan pertanian.

Penyuluhan harus diawali oleh kesadaran akan adanya kebutuhan manusia untuk mengembangkan dirinya agar lebih mampu meningkatkan kesejahteraan hidupnya. Oleh karena itu kegiatan penyuluhan perlu dikembangkan dalam rangka menggerakkan kesadaran dan partisipasi masyarakat dalam proses pembangunan agar memiliki kemampuan menolong dirinya sendiri untuk mencapai tujuan perbaikan mutu hidup dan kesejahteraan yang dicita-citakan (Mardikanto 1993 dan Muljono 2007).

\section{b) Kesesuaian Materi Penyuluhan}

Hasil penelitian menunjukkan bahwa kesesuaian materi penyuluhan berada pada ketegori sangat sesuai dengan rataan 23. Hal ini menunjukkan bahwa materi penyuluhan yang diberikan kepada responden dinilai telah sesuai dengan kebutuhan dan dapat membantu responden dalam mengambil tindakan terhadap penyelesaian setiap permasalahan dalam usahatani padi sawah. Penyampaian materi pada petani diberikan oleh instansi terkait (dinas pertanian setempat, UPTD). Selain itu materi juga diberikan oleh keujruen blang yang telah berpengalaman di bidang pertanian. Hal ini bertujuan agar petani dapat belajar dengan petani lain serta saling berbagi pengalaman usahatani padi sawah. Materi dalam kegiatan penyuluhan meliputi pengetahuan dalam pendayagunaan dan pelestarian musuh alami, cara budidaya tanaman, pemeliharaan serta pengairan yang cukup. Materi penyuluhan menurut UU No. 16 Tahun 2006 adalah bahan penyuluhan yang akan disampaikan oleh para penyuluh kepada pelaku utama dan pelaku usaha dalam berbagai bentuk yang meliputi informasi, teknologi, rekayasa, sosial, manajemen, ekonomi, hukum, dan kelestarian lingkungan.

\section{c) Kesesuaian Media Penyuluhan}

Kesesuaian media penyuluhan berada pada kategori sangat sesuai dengan rataan 13. Hal tersebut menunjukkan bahwa media penyuluhan yang digunakan sudah sesuai, yang berarti mampu menarik minat, mempermudah pemahaman materi yang disampaikan. Media yang dimanfaatkan atau digunakan berupa brosur usahatani. Selain itu juga memanfaatkan media elektronik berupa leptop dan infocus agar materi dapat didengar dan dilihat secara jelas oleh petani. Hasil penelitian menyimpulkan bahwa buku bergambar untuk mengenal musuh alami memudahkan petani mengenal dan mengidentifikasi musuh alami di lahan. Di sisi lain, praktek langsung di lahan sawah memudahkan petani dalam penentuan pola tanam $(2: 1 / 4: 1)$ dengan menggunakan caplak kayu untuk mengatur jarak tanam padi jajar legowo. Menurut van den Ban dan Hawkins (1999) bahwa media adalah alat penyampai atau pengantar suatu materi pesan sehingga dapat sampai kepada penerima. Memanfaatkan media yang mudah dan inovatif dapat meningkatkan pemahaman peserta penyuluhan. Media yang digunakan di desa penelitian berupa media cetak dan elektronik.

\section{d) Ketepatan Metode Penyuluhan}

Ketepatan metode penyuluhan dalam penelitian ini berada pada kategori cukup sesuai dengan rataan 12. Hal tersebut menunjukkan pemilihan metode penyuluhan yang cukup mampu membangkitkan minat, dan mempermudah pemahaman materi yang 
sampaikan. Kondisi tersebut menunjukkan bahwa cukup sesuai dalam penggunaan metode penyuluhan yang dipilih dapat menunjang keberhasilan materi yang diberikan seperti metode penyuluhan yang dilakukan meliputi ceramah, diskusi, kunjungan usahatani, demonstrasi cara dan hasil. Hal ini berbeda dengan Mardikanto (2009) yang menyatakan bahwa efektivitas suatu metode penyuluhan ditentukan oleh pemilihan suatu metode yang tepat, namun tidak berarti suatu metode lebih baik dibanding dengan metode yang lain karena tidak ada satupun metode penyuluhan yang selalu efektif digunakan pada semua kegiatan penyuluhan tetapi perlu diterapkan secara kombinasi sesuai kebutuhan.

\section{Persepsi Petani tentang Kompetensi Keujruen Blang dalam Pengembangan Pertanian}

Persepsi petani tentang kompetensi keujruen blang dalam pengembangan pertanian yang diteliti terdiri dari: menentukan dan mengkoordinasikan tata cara turun ke sawah, mengatur pembagian air ke sawah petani, membantu pemerintah dalam bidang pertanian, mengkoordinasikan khanduri blang atau upacara lain yang berkaitan dengan adat usaha pertanian, memberi teguran dan sanksi kepada petani yang melanggar aturan-aturan adat meugoe (bersawah) atau tidak melaksanakan kewajiban lain dalam sistem pelaksanaan pertanian sawah secara adat, dan menyelesaikan sengketa antar petani yang berkaitan dengan pelaksanaan usaha pertanian sawah. Jumlah dan persentase berdasarkan tingkat persepsi petani tentang kompetensi keujruen blang dalam pengembangan pertanian tersebut disajikan pada Tabel 3.

\section{a. Persepsi petani tentang tata cara turun sawah}

Hasil penelitian pada Tabel 3 tentang persepsi petani tentang tata cara turun sawah sebagian besar berada pada kategori tinggi cenderung sedang dengan rataan 14. Hal ini menunjukkan bahwa persepsi petani tentang keujruen blang sudah baik dalam pengaturan tata cara turunke sawah. Hal ini dikarenakan mengkoordinasikan tata cara turun ke sawah berdasarkan hasil musyawarah di kecamatan yang diadakan oleh keujruen blang yang melibatkan UPTD, kepala desa, dan ketua kelompok tani. Kemudian setelah ditetapkan hasil rapat, keujruen blang menginformasikan kepada masyarakat tani

Tabel 3. Jumlah dan Persentase Petani berdasarkan Kategori Persepsi Petani tentang Kompetensi Keujruen Blang dalam Pengembangan Pertanian di Kabupaten Aceh Besar pada Tahun 2017

\begin{tabular}{llcr}
\hline \multicolumn{1}{c}{$\begin{array}{c}\text { Persepsi Petani tentang kompetensi } \\
\text { Keujruen Blang }\end{array}$} & \multicolumn{1}{c}{ Kategori } & Jumlah (orang) & Persentase (\%) \\
\hline Tata cara turun ke sawah & Rendah (1-6) & 8 & 8,00 \\
Rataan $=14$ & Sedang (7-12) & 24 & 24,00 \\
& Tinggi (13-18) & 68 & 68,00 \\
Pengaturan pembagian air & Rendah (1-6) & 10 & 10,00 \\
Rataan=14 & Sedang (7-12) & 18 & 18,00 \\
& Tinggi (13-18) & 72 & 72,00 \\
Koordinasi dengan pemerintah & Rendah (1-5) & 18 & 18,00 \\
Rataan=9 & Sedang (6-10) & 73 & 73,00 \\
& Tinggi (11-15) & 9 & 9,00 \\
Mengkoordinasikan khanduri blang & Rendah (1-6) & 13 & 13,00 \\
Rataan=16 & Sedang (7-12) & 1 & 1,00 \\
& Tinggi (13-18) & 86 & 86,00 \\
Pemberian teguran dan sanksi & Rendah (1-6) & 23 & 23,00 \\
Rataan=12 & Sedang (7-12) & 35 & 35,00 \\
& Tinggi (13-18) & 42 & 42,00 \\
Penyelesaian sengketa antar petani & Rendah (1-7) & 41 & 41,00 \\
Rataan=11 & Sedang (8-14) & 35 & 35,00 \\
& Tinggi (15-21) & 24 & 24,00 \\
\hline
\end{tabular}


bahwa pada tanggal dan bulan tertentu jatah air untuk setiap masing-masing hamparan sawah, membersihkan saluran irigasi, waktu membajak sawah (mengolah tanah), masa merendam benih, waktu penanaman padi dan pada awal Agustus semua aktivitas usahatani sudah selesai yang menandakan memasuki masa $t o b$ blang (tutup sawah) semua aktivitas tidak boleh lagi dilakukan.

\section{b) Persepsi Petani tentang Pengaturan Pembagian Air}

Hasil penelitian tentang persepsi petani tentang pengaturan pembagian air berada pada kategori tinggi dengan rataan 14. Hal ini menunjukkan bahwa persepsi petani terhadap keujruen blang sudah sangat baik dalam pengaturan pembagian air ke sawah petani. Hal ini dikarenakan petani merasa dengan adanya keujruen blang petani mendapatkan penyaluran air tepat waktu karena sistem penyaluran air yang diterapkan oleh keujruen blang adalah menyalurkan air ke tempat yang paling jauh terlebih dahulu karena sawah yang dekat dengan irigasi mudah dan cepat penyaluran air.

\section{c) Persepsi Petani tentang Koordinasi dengan Pemerintah}

Hasil penelitian tentang persepsi petani tentang koordinasi dengan pemerintah sebagian berada pada kategori sedang $(73,00$ persen) dengan rataan 9 . Hal ini menunjukkan bahwa persepsi petani terhadap keujruen blang sudah baik dalam mengkoordinasikan dengan pihak pemerintah. Hal tersebut dikarenakan keujruen blang membantu penyuluh dalam mengumpulkan petani pada saat kegiatan penyuluhan. Selain itu, keujruen blang dibantu oleh ketua kelompok tani juga ikut mendata masyarakat tani agar penyuluh dengan mudah mengetahui programa apa yang harus disosialisasikan ke masyarakat tani. Petani merasa sangat terbantu dengan peran keujruen blang dan ketua kelompok tani dalam usahatani padi sawah.

\section{d) Persepsi Petani tentang Mengkoordinasikan Khanduri Blang}

Hasil penelitian tentang persepsi petani tentang mengkoordinasikan khanduri blang sebagian besar berada pada kategori tinggi (86,00 persen) dengan rataan 16. Hal ini menunjukkan bahwa persepsi petani terhadap keujruen blang sudah sangat baik dalam mengkoordinasikan khanduri blang. Hal tersebut menunjukkan bahwa keujruen blang melakukan musyawarah dengan petani untuk menentukan jadwal dan persiapannya yang harus di persiapkan masyarakat tani pada hari khaduri blang. Masyarakat tani diwajibkan mambawa bu kulah (nasi bungkus) 2-3 bungkus/orang sedangkan menu makanannya tidak ditentukan sesuai dengan kemampuan petani, nantinya nasi bungkus tersebut dibagikan kepada tamu undangan. Pada lokasi penelitian ada juga masyarakat tani tidak dibenarkan untuk membawa nasi bungkus (bu kulah) karena acara khanduri blang diadakan tingkat kecamatan maka setiap petani menyumbang biaya sukarelawan untuk acara khanduri blang, biaya sukarelawan tersebut dipergunakan untuk membeli sapi, beras dan keperluan yang dianggap dibutuhkan kemudian dimasak bersama-sama dengan masyarakat tani pada lokasi khanduri blang.

\section{e) Persepsi Petani tentang Pemberian Teguran dan Sanksi}

Hasil penelitian tentang persepsi petani tentang pemberian teguran dan sanksi berada pada kategori tinggi cenderung sedang dengan rataan 12 . Hal ini menunjukkan bahwa persepsi petani terhadap keujruen blang sudah baik dalam pemberian teguran dan sanksi kepada petani pelanggar aturan bersawah. Hal tersebut dikarenakan bahwa keujruen blang memberi teguran atau sanksi kepada petani pelanggar sehingga tidak akan mengulangnya dan ini juga sangat bermanfaat untuk petani lainnya menghindari hal-hal yang tidak di inginkan selama berusahatani padi sawah.

\section{f) Persepsi Petani tentang Penyelesaian Sengketa Antar Petani}

Petani yang berada dalam kawasan hamparan sawah yang dikelola oleh keujruen blang bila terlibat sengketa dalam usahatani maka akan mendapat teguran dan sanksi dari keujruen chik atau keujruen muda yang melanggar aturan bersawah. Persepsi petani tentang penyelesaian sengketa antarpetani dalam penelitian ini berada pada kategori rendah cenderung sedang dengan rataan 11. Hal ini menunjukkan bahwa persepsi petani terhadap keujruen blang belum cukup baik dalam penyelesaian sengketa antarpetani dan pelanggar 
aturan bersawah. Kondisi tersebut menunjukkan bahwa petani merasa perlu ada upaya khusus dari keujruen blang dalam menyelesaikan sengketa antarpetani.

\section{Hubungan Karakteristik Petani dengan Tingkat Persepsi Petani tentang Kompetensi Keujruen Blang dalam Pengembangan Pertanian}

Hasil penelitian sebagaimana ditampilkan pada Tabel 4, menunjukkan bahwa karakteristik tingkat pendapatan berhubungan dengan tingkat persepsi petani tentang kompetansi keujruen blang dalam pengembangan pertanian pada aspek pemberian teguran dan sanksi, dan penyelesaian sengketa antarpetani, sedangkan pengalaman usahatani berhubungan dengan tingkat persepsi petani tentang kompetensi keujruen blang dalam pengembangan pertanian pada aspek koordinasi dengan pemerintah. Sebaliknya karakteristik umur, tingkat pendidikan formal, jumlah tanggungan, luas lahan garapan dan tingkat kekosmopolitan tidak berhubungan nyata dengan tingkat persepsi petani tentang kompetensi keujruen blang dalam pengembangan pertanian.
Tingkat pendapatan berhubungan nyata dengan tingkat persepsi petani tentang kompetensi keujruen blang dalam pengembangan pertanian. Hal ini menunjukkan bahwa semakin tinggi tingkat pendapatan seseorang maka tingkat persepsi petani tentang kompetensi keujruen blang tentang pemberian tenguran dan sanksi semakin meningkat. Kondisi tersebut disebabkan bahwa petani yang melangar aturan meugoe (bersawah) seperti pencurian air yang berujung pada perkelahian sehingga keujruen blang memberi teguran dan sanksi kepada petani pelanggar tersebut. Jika perkelahiannya sampai mengakibatkan tumpah darah maka petani tersebut dikenakkan sanksi memotong kambing di sawah.

Tingkat pendapatan berhubungan nyata dengan tingkat persepsi petani tentang kompetensi keujruen blang dalam pengembangan pertanian tentang penyelesaian sengketa antarpetani. Hal tersebut menunjukkan bahwa semakin tinggi tingkat pendapatan seseorang maka tingkat persepsi petani tentang kompetensi keujruen blang tentang penyelesaian sengketa antarpetani semakin meningkat. Hal tersebut menunjukkan

Tabel 4. Nilai Koefisien Korelasi dan Signifikansi Hubungan Karakteristik Petani dengan Tingkat Persepsi Petani tentang Kompetensi Keujruen Blang dalam Pengembangan Pertanian di Kabupaten Aceh Besar pada Tahun 2017

\begin{tabular}{lcccccc}
\hline & \multicolumn{6}{c}{ Tingkat Persepsi Petani tentang Kompetensi Keujruen } \\
Kang dalam Pengembangan Pertanian \\
\cline { 2 - 7 } \multicolumn{1}{c}{ Karakteristik petani } & TCTS & PPA & KdP & P.KB & PTdS & Psap \\
\hline Umur & $-0,005$ & 0,027 & 0,193 & $-0,003$ & 0,079 & $-0,017$ \\
Tingkat pendidikan formal & $-0,076$ & $-0,134$ & $-0,008$ & $-0,100$ & 0,050 & 0,083 \\
Jumlah tanggungan keluarga & $-0,099$ & $-0,011$ & 0,065 & $-0,040$ & 0,063 & $-0,009$ \\
Luas lahan garapan & 0,072 & 0,109 & 0,106 & 0,081 & 0,011 & 0,024 \\
Pengalaman usahatani & 0,064 & 0,184 & $0,225^{*}$ & 0,076 & 0,106 & $-0,007$ \\
Tingkat pendapatan & 0,167 & 0,027 & 0,031 & $-0,005$ & $0,279^{* *}$ & $0,344^{* *}$ \\
Tingkat kekosmopolitan & 0,133 & $-0,085$ & 0,079 & 0,122 & $-0,072$ & 0,019 \\
\hline
\end{tabular}

Keterangan:

Tata cara turun sawah (TCTS)

Pengaturan pembagian air (PPA)

Koordinasi dengan pemerintah (KdP)

Pengoordinasikan khanduri blang (P.KB)

Pemberian teguran dan sanksi (PTdS)

Penyelesaian sengketa antarpetani (Psap)

* korelasi signifikan pada taraf kepercayaan 95 persen $(a=0.05)$

** korelasi signifikan pada taraf kepercayaan 99 persen $(a=0.01)$ 
bahwa keujreun blang dalam pengambilan keputusan terhadap penyelesaian sengketa antarpetani melalui jalur musyawarah dengan petani yang terlibat sengketa sehingga petani yang dinyatakan bersalah dikenakkan sanksi berupa uang atau emas sebagai imbalan atas kesalahanya. Menurut Soekartawi (1988) bahwa pendapatan petani yang tinggi sering kali berhubungan dengan kemauan untuk melakukan perubahan, begitupun sebaliknya petani yang berpenghasilan rendah adalah lambat dalam melakukan suatu perubahan atau dalam mencoba sesuatu.

Pengalaman usahatani berhubungan nyata dengan tingkat persepsi petani tentang kompetensi keujruen blang dalam pengembangan pertanian tentang koordinasi dengan pemerintah. Hal ini menunjukkan bahwa petani yang sudah lama bertani akan lebih mudah untuk menerapkan inovasi dari pada petani pemula maka persepsi petani tentang kompetensi keujruen blang tentang koordinasi dengan pemerintah semakin meningkat. Kondisi ini dikarenakan bahwa pengalaman yang lebih banyak dalam berusahatani maka petani mengetahui bahwa keujruen blang berkoordinasi dengan pemerintah tentang program yang akan disosialisasikan kepada petani. Mardikanto (1993) menyebutkan bahwa pengalaman yang dimiliki seseorang akan mempengaruhi proses pengambilan keputusan, sehingga petani yang memiliki pengalaman berusahatani lebih lama cenderung akan selektif dalam proses pengambilan keputusan dibandingkan dengan petani yang memiliki pengalaman yang sedikit.

Umur merupakan suatu faktor yang berhubungan dengan kemampuan fisik petani baik dalam berpikir maupun mengambil tindakan terhadap usahataninya. Hasil penelitian menunjukkan bahwa faktor umur tidak berhubungan nyata dengan tingkat persepsi petani tentang kompetensi keujruen blang dalam pengembangan pertanian. Hal tersebut menunjukkan bahwa semakin bertambahnya umur belum tentu dapat meningkatkan persepsi petani tentang lembaga adat keujruen blang. Kondisi ini disebabkan bertambahnya umur petani tidak diiringi dengan peningkatan pengetahuan petani terhadap peran keujruen blang dalam pengelolaan wilayah hamparan sawah. Hasil penelitian ini sejalan dengan penelitian Azwar (2016) bahwa semakin bertambahnya umur belum tentu dapat meningkatkan persepsi petani terhadap manfaat keberadaan program dan tingkat kemudahan pelaksanaan kegiatan rehabilitasi tanaman kakao.

Tingkat pendidikan formal tidak berhubungan nyata dengan tingkat persepsi petani tentang kompetensi keujruen blang dalam pengembangan pertanian. Hal tersebut menunjukkan bahwa semakin tinggi tingkat pendidikan formal petani belum tentu dapat meningkatkan persepsi petani tentang kompetensi keujruen blang. Hal tersebut dikarenakan semakin tinggi tingkat pendidikan formal petani tidak diiringi dengan peningkatan pengetahuan petani terhadap peran keujreun blang dalam pengembangan pertanian. Hal tersebut tidak sejalan dengan penelitian Manoppo (2009) yang menemukan bahwa tingkat pendidikan menentukan kemampuan seseorang dalam mencerna informasi yang diberikan berhubungan dengan kualitas kerja dalam melakukan usahatani. Wanita tani yang berpendidikan tinggi lebih bisa membudidayakan kakao ke arah agribisnis, bukan sekedar pemenuhan kebutuhan keluarga saja.

Jumlah tanggungan keluarga tidak berhubungan nyata dengan tingkat persepsi petani tentang kompetensi keujruen blang dalam pengembangan pertanian. Hal ini menunjukkan bahwa semakin banyak jumlah anggota keluarga petani yang ditanggung oleh kepala keluarga, tidak mempengaruhi terhadap tingkat persepsi petani tentang kompetensi keujruen blang. Kondisi tersebut disebabkan peran keluarga hanya berperan kecil dalam proses usahatani padi sawah mulai dari persemaian, penanaman, panen dan pascapanen. Hal ini sejalan dengan penelitian Azwar (2016) bahwa banyak atau sedikit jumlah tanggungan keluarga belum tentu meningkatkan persepsi petani dalam melihat suatu program.

Luas lahan garapan tidak berhubungan nyata dengan tingkat persepsi petani tentang kompetensi keujruen blang dalam pengembangan pertanian. Hal ini menunjukkan bahwa semakin bertambah luas lahan garapan yang dimiliki petani secara nyata tidak dapat meningkatkan tingkat persepsi petani tentang kompetensi keujruen blang. Kondisi ini disebabkan bertambah luas atau tidaknya lahan garapan bukan merupakan faktor yang dapat meningkatkan persepsi petani tentang kompetensi keujruen blang dalam pengembangan pertanian.

Tingkat kekosmopolitan tidak berhubungan nyata 
dengan tingkat persepsi petani tentang kompetensi keujruen blang dalam pengembangan pertanian. Hal ini menunjukkan bahwa semakin tinggi tingkat kekosmopolitan tidak berati dapat meningkatkan tingkat persepsi petani tentang kompetensi keujruen blang. Kondisi ini menunjukkan bahwa setiap kegiatan lembaga adat keujruen blang tidak memerlukan tingkat kekosmopolit tertentu, karena setiap kegiatan usahatani dilalukan secara bersama-sama dengan petani. Hal ini sejalan dengan penelitian Budiono et al. (2006) bahwa semakin tinggi tingkat kekosmopolitan tidak berpengaruh pada meningkatnya pendapatan petani, karena upaya petani dalam meningkatkan kualitas pengetahuan di bidang kehutanan dan pertanian konservasi bertujuan untuk memenuhi kebutuhan dasar.

\section{Hubungan Kegiatan Penyuluhan dengan Tingkat Persepsi Petani tentang Kompetensi Keujruen Blang dalam Pengembangan Pertanian}

Hasil penelitian sebagaimana ditampilkan pada Tabel 5, menunjukkan faktor-faktor pada variabel kegiatan penyuluhan yang diteliti adalah intensitas mengikuti penyuluhan, kesesuaian materi penyuluhan, kesesuaian media penyuluhan dan ketepatan metode penyuluhan, memiliki hubungan positif dan nyata dengan tingkat persepsi petani tentang kompetensi keujruen blang dalam pengembangan pertanian. Temuan tersebut mempertegas bahwa aktivitas penyuluhan berperan penting dalam meningkatkan persepsi petani tentang kompetensi keujruen blang. Hal tersebut menandakan semakin tinggi kegiatan penyuluhan yang dilaksanakan maka tingkat persepsi petani akan meningkat seiring dengan berjalannya waktu.

Kesesuaian materi penyuluhan berhubungan nyata dengan tingkat persepsi petani tentang kompetensi keujruen blang tentang tata cara turun kesawah, pengaturan pembagian air, koordinasi dengan pemerintah, mengkoordinasikan khanduri blang, dan pemberian teguran dan sanksi. Hal ini menunjukkan bahwa semakin sesuai materi penyuluhan yang disampaikan maka persepsi petani tentang kompetensi keujruen blang tentang tata cara turun ke sawah semakin meningkat. Hal ini dikarenakan bahwa semakin sesuai penyuluhan yang disampaikan penyuluh dengan kebutuhan petani maka petani mengetahui bahwa tata cara turun kesawah sudah dimusyawarahkan dengan lembaga adat keujruen blang kapan waktu yang tepat dan sesuai untuk turun sawah serentak berdasarkan pengamatan keuneunong (kelender prakiraan) oleh keujruen blang, kemudian keuneunong tersebut disesuaikan dengan jadwal tanam

Tabel 5. Nilai Koefisien Korelasi dan Signifikansi Hubungan Kegiatan Penyuluhan dengan Tingkat Persepsi Petani tentang Kompetensi Keujruen Blang dalam Pengembangan Pertanian di Kabupaten Aceh Besar pada Tahun 2017

\begin{tabular}{|c|c|c|c|c|c|c|}
\hline \multirow[t]{2}{*}{ Kegiatan penyuluhan } & \multicolumn{6}{|c|}{$\begin{array}{c}\text { Tingkat persepsi petani tentang kompetensi keujruen blang } \\
\text { dalam pengembangan pertanian }\end{array}$} \\
\hline & TCTS & PPA & KdP & P.KB & PTdS & Psap \\
\hline Intensitas mengikuti penyuluhan & 0,151 & $-0,032$ & 0,119 & 0,111 & 0,127 & $0,216^{*}$ \\
\hline Kesesuaian materi penyuluhan & $0,320 * *$ & $0,269 * *$ & $0,456 * *$ & $0,282 * *$ & $0,280 * *$ & 0,109 \\
\hline Kesesuaian media penyuluhan & 0,134 & $0,353 * *$ & $0,266 * *$ & 0,091 & $0,354 * *$ & $0,225^{*}$ \\
\hline Ketepatan metode penyuluhan & 0,194 & $0,361 * *$ & 0,111 & 0,079 & 0,105 & 0,194 \\
\hline
\end{tabular}

Keterangan:

Tata cara turun sawah (TCTS)

Pengaturan pembagian air (PPA)

Koordinasi dengan pemerintah (KdP)

Pengoordinasikan khanduri blang (P.KB)

Pemberian teguran dan sanksi (PTdS)

Penyelesaian sengketa antarpetani (Psap)

* korelasi signifikan pada taraf kepercayaan 95 persen $(a=0.05)$

$* *$ korelasi signifikan pada taraf kepercayaan 99 persen $(a=0.01)$ 
padi (UPTD) dan seterusnya diinformasikan ke petani. Menurut Mardikanto (2009) bahwa materi penyuluhan pada hakekatnya merupakan segala pesan yang ingin dikomunikasikan oleh penyuluh kepada masyarakat penerima manfaat.

Kesesuaian materi penyuluhan berhubungan nyata dengan tingkat persepsi petani tentang kompetensi keujruen blang tentang pengaturan pembagian air. Hal ini membuktikan bahwa semakin sesuai materi penyuluhan yang disampaikan maka persepsi petani tentang kompetensi keujruen blang tentang pengaturan pembagian air semakin meningkat. Hal ini dikarenakan semakin sesuai materi yang disampaikan penyuluh dengan kebutuhan petani maka petani mengetahui bahwa pengaturan pembagian air ditentukan oleh lembaga adat keujruen blang. Kondisi tersebut dikarenakan bahwa pembagian air untuk setiap kecamatan berdasarkan jadwal yang telah ditentukan berdasarkan hasil rapat keujruen blang dengan dinas pekerjaan umum yang membawahi bagian pengairan (PU) Kabupaten Aceh Besar. Kemudian pengaturan pembagian air di wilayah mukin dalam kecamatan tersebut dilakukan oleh keujruen muda bertujuan agar petani mendapatkan air secara merata dan adil. Manurut Mardikanto (2009) bahwa materi penyuluh tidak harus bersumber dari textbook, tetapi dapat dari media massa (koran, tabloid, majalah, laporan-laporan, radio, televisi, internet dan lain-lain) termasuk cerita rakyat maupun pesan-pesan generasi tua (para pendahulu), maupun pengalaman kerja dan pengalaman hidup sehari-hari.

Kesesuaian materi penyuluhan berhubungan nyata dengan tingkat persepsi petani tentang kompetensi keujruen blang tentang koordinasi dengan pemerintah. Hal ini menunjukkan bahwa semakin sesuai materi penyuluhan yang disampaikan dengan kebutuhan petani maka persepsi petani tentang kompetensi keujruen blang tentang koordinasi dengan pemerintah semakin meningkat. Hal tersebut dikarenakan petani mengetahui bahwa keujruen blang telah berkoordinasi dengan pemerintah agar dapat membantu petani berupa pengadaan pengolahan lahan, benih, pupuk dan pestisida. Menurut Soekartawi (1988) Semakin lama petani mengelola usahataninya maka diharapkan petani semakin rasional dalam mengambil keputusan sehingga dalam berusahatani akan semakin berhasil.

Kesesuaian materi penyuluhan berhubungan nyata dengan tingkat persepsi petani tentang kompetensi keujruen blang tentang mengkoordinasikan khanduri blang. Hal ini menunjukkan bahwa semakin sesuai materi penyuluhan yang disampaikan penyuluh dengan kebutuhan petani maka persepsi petani tentang kompetensi keujruen blang tentang mengkoordinasikan khanduri blang semakin meningkat. Hal ini dikarenakan petani mengetahui bahwa keujruen blang telah melakukan pengoordinasian khanduri blang sehingga petani secara bersama-sama memohon do'a mensyukuri hasil panen tahun lalu dan berharap agar hasil panen kedepan jauh lebih baik. Menurut Knowles dalam Yumi et al (2011) orientasi belajar orang dewasa adalah aplikasi belajar yang langsung dimanfaatkan sehingga materi pembelajaran berorientasi atau fokus perhatian peserta belajar.

Kesesuaian materi penyuluhan berhubungan nyata dengan tingkat persepsi petani tentang kompetensi keujruen blang tentang pemberian teguran dan sanksi. Hal ini menunjukkan bahwa semakin sesuai materi penyuluhan yang disampaikan penyuluh dengan kebutuhan petani maka persepsi petani tentang kompetensi keujruen blang tentang pemberian teguran dan sanksi semakin meningkat. Hal tersebut dikarenajkan petani mengetahui bahwa keujruen blang yang memberi teguran dan sanksi kepada petani yang melanggar aturan bersawah di wilayah tersebut. Hal ini seperti kasus petani yang melubangi pematang sawah agar air lebih banyak mengalir ke sawahnya. Saylor dan Alexander (1996) mengemukakan bahwa karakteristik materi pelatihan yang baik harus memenuhi beberapa aspek yaitu relevansi terhadap sasaran kegiatan, materi disesuaikan dengan kegunaan pemakaian, isi materi pelatihan harus memberi informasi yang tepat dan mempertimbangkan faktor ekonomi.

Kesesuaian media penyuluhan berhubungan nyata dengan tingkat persepsi petani tentang kompetensi keujruen blang tentang pengaturan pembagian air, koordinasi dengan pemerintah, pemberian teguran dan sanksi, dan penyelesaian sengketa antarpetani. Hal ini menunjukkan bahwa semakin sesuai media yang digunakan dan dibantu dengan penjelasan oleh tenaga terampil (penyuluh / keujruen blang) maka persepsi petani tentang kompetensi keujruen blang tentang pengaturan pembagian air semakin meningkat. Hal ini dikarenakan petani mengetahui bahwa keujruen blang yang mengatur pembagian air di wilayah tersebut. 
Keujruen blang menyalurkan air sesuai jadwal yang telah ditetapkan oleh dinas pekerjaan umum yang membawahi bagian pengairan (PU) Kabupaten Aceh Besar. Pertiwi et al. (2010) menemukan bahwa penyajian informasi tentang penanggulangan hama penyakit tanaman, pemupukan dan pemanenan melalui televisi mampu memberikan informasi lebih baik, karena siaran tidak saja dapat didengarkan tetapi juga dilihat.

Kesesuaian media penyuluhan berhubungan nyata dengan tingkat persepsi petani tentang kompetensi keujruen blang tentang koordinasi dengan pemerintah. Hal ini menunjukkan bahwa semakin sesuai media yang digunakan dan dibantu dengan penjelasan oleh tenaga terampil (penyuluh/keujruen blang) maka persepsi petani tentang kompetensi keujruen blang tentang koordinasi dengan pemerintah semakin meningkat. Hal ini menunjukkan bahwa keujruen blang telah mampu berkoordinasi dengan pemerintah untuk memperoleh informasi tentang usahatani, mengupayakan mendapatkan bantuan sarana produksi dan penyesuaian keuneunong (perkiraan jadwal tanam) dengan jadwal tanam Unit Pelaksana Teknik Daerah (UPTD). Pulungan (2008) mengemukakan bahwa media penyuluhan merupakan semua sarana atau upaya untuk menampilkan pesan atau informasi yang ingin disampaikan oleh komunikator, baik itu melalui media cetak, elektronik dan media luar ruang sehingga sasaran dapat meningkatkan pengetahuannya yang pada akhirnya diharapkan dapat mengubah perilaku kearah positif.

Kesesuaian media penyuluhan berhubungan nyata dengan tingkat persepsi petani tentang kompetensi keujruen blang tentang pemberian teguran dan sanksi. Hal ini menunjukkan bahwa semakin sesuai media yang digunakan dan dibantu dengan penjelasan oleh tenaga terampil (penyuluh/keujruen blang) maka persepsi petani tentang kompetensi keujruen blang tentang pemberian teguran dan sanksi semakin meningkat. Hal ini dikarenakan petani mengetahui bahwa keujruen blang yang memberi teguran dan sanksi kepada petani pelanggar aturan bersawah. Kondisi tersebut karena pemberian teguran dan sanksi adalah tugas dan tanggung jawab keujruen blang dalam menyelesaikan setiap permasalah diantara petani yang berada dalam kawasan hamparan sawah yang dikuasai oleh keujruen blang. Sawerah et al. (2016) menyatakan bahwa media sebagai alat mengakses informasi dapat memberikan rangsangan, yang menimbulkan kreativitas kepada seseorang yang menguasainya untuk melakukan suatu aktivitas. Sari et al. (2016) bahwa media bergambar untuk mengenal musuh alami di lahan memudahkan responden untuk mengenal dan mengidentifikasi musuh alami.

Kesesuaian media penyuluhan berhubungan nyata dengan tingkat persepsi petani tentang kompetensi keujruen blang tentang penyelesaian sengketa antarpetani. Hal ini menunjukkan bahwa semakin sesuai media yang digunakan dan dibantu dengan penjelasan oleh tenaga terampil (penyuluh/keujruen blang) maka persepsi petani tentang kompetensi keujruen blang tentang penyelesaian sengketan antarpetani semakin meningkat. Hal ini dikarenakan petani mengetahui bahwa keujruen blang yang bertugas menyelesaikan sengketa antarpetani di wilayah hamparan sawah tersebut. Sari (2016) menyatakan bahwa penggunaan media penyuluhan oleh penyuluh dapat dilihat dari sifatnya yaitu media mati dan media hidup, dimana media mati berupa sarana yang dapat digunakan sebagai penghubungan materi oleh penyuluh dengan sasaran berupa media massa, brosur, pamflet, dan lain-lain. Media hidup yaitu seseorang yang memiliki pengalaman atau pengetahuan dari bidang pertanian, yang dapat menyampaikan pengalaman dan berbagi informasi kepada sasaran penyuluhan.

Ketepatan metode penyuluhan berhubungan nyata dengan tingkat persepsi petani tentang kompetensi keujruen blang tentang pengaturan pembagian air. Hal ini menunjukkan bahwa pemilihan metode diskusi dan ceramah dapat meningkatkan persepsi petani tentang kompetensi keujruen blang tentang pengaturan pembagian air semakin meningkat. Kondisi tersebut menunjukkan bahwa diskusi dan ceramah yang dilakukan dengan petani membicarakan terkait dengan waktu pembagian air. Metode diskusi dan ceramah lebih memudahkan petani padi sawah dalam memahami materi yang diberikan penyuluh karena petani dapat bertanya dan berdiskusi dengan sesama anggota secara langsung apabila ada hal-hal yang belum dipahami dengan baik. Hasil penelitian ini didukung oleh Tahitu (2015) bahwa ketepatan metode penyuluhan dapat membantu petani memahami materi yang diberikan penyuluh. Mardikanto (2009) menyatakan bahwa dalam memilih metode penyuluhan didasarkan pada: 
(1) media yang digunakan, (2) sifat hubungan antara penyuluh dan penerima manfaat, dan (3) pendekatan psikososial.

Intensitas mengikuti penyuluhan berhubungan nyata dengan tingkat persepsi petani tentang kompetensi kuejruen blang tentang penyelesaian sengketa antarpetani dalam pengembangan pertanian. Hal ini menunjukkan bahwa semakin sering petani hadir pada kegiatan penyuluhan maka persepsi petani tentang kompetensi keujruen blang tentang penyelesaian sengketa antarpetani semakin meningkat. Kondisi tersebut karena petani telah mengetahui jadwal kegiatan penyuluhan yang dilaksanakan sebanyak 3 kali dalam sebulan dan telah terjadwal sepanjang tahun yang tertera dalam buku programa penyuluhan yang disesuaikan dengan programa-programa pemerintah yang secara operasional di lapangan sangat terkait dengan tugas penyuluh pertanian. Menurut Wiraatmadja (1990) bahwa dalam pelaksanaan penyuluhan, seseorang penyuluh harus saling berhubungan, hubungan tersebut pada akhirnya dapat menimbulkan komunikasi untuk saling bertukar informasi.

\section{Kesimpulan}

Petani memiliki persepsi tinggi terhadap tingkat kompetensi keujruen blang dalam pengembangan pertanian yang berarti keujruen blang dinilai telah mampu menjalankan perannya dengan baik. Keujruen blang dinilai memiliki kompetensi yang tinggi pada aspek tata cara turun ke sawah, pengaturan pembagian air, koordinasi dengan pemerintah, mengkoordinasikan khanduri blang, dan pemberian teguran dan sanksi. Sebaliknya pada aspek penyelesaian sengketa antar petani kompetensinya dinilai masih rendah. Pemerintah pusat maupun daerah perlu bermitra dengan lembaga adat keujruen blang dalam penataan pembangunan pertanian. Pemerintah perlu menjadikan keujruen blang sebagai penyuluh swadaya, dengan adanya penyuluh swadaya seperti keujruen blang dapat meningkatkan interaksi antara petani dan penyuluh, sehingga memudahkan pihak pemerintah dalam mengembangkan dan membangun kerja sama yang baik dengan petani maupun penyuluh.

Faktor-faktor yang berhubungan nyata dengan tingkat persepsi petani tentang kompetensi keujruen blang dalam pengembangan pertanian adalah kesesuaian materi penyuluhan, kesesuaian media penyuluhan, tingkat pendapatan, ketepatan metode penyuluhan, pengalaman usahatani, dan intensitas mengikuti penyuluhan. Penyuluh pertanian perlu meningkatkan intensitas penggunaan media elektronik supaya petani mudah memahami materi yang disampaikan pada saat kegiatan penyuluhan. Dalam hal ini pemerintah pusat maupun daerah perlu mempertimbangkan untuk menambah jumlah media yang dibutuhkan penyuluh untuk menyuluh agar dapat menunjang peningkatan pengetahuan petani.

\section{Daftar Pustaka}

Azwar. 2016. Persepsi dan partisipasi petani dalam pelaksanaan kegiatan rehabilitasi tanaman kakao di Kabupaten Sigi Provinsi Sulawesi Tengah [tesis]. Bogor (ID): Institut Pertanian Bogor.

Budiono P, Jahi A, Slamet M, Susanto D. 2006. Hubungan karakteristik petani tepi hutan dengan perilaku mereka dalam melestarikan hutan lindung di 12 Desa Provinsi Lampung. Jurnal Penyuluhan. 2(2): 44-52.

Ehrenberg RG, Smith RS. 1988. Modern Labor Economic: Theory and Public Policy. London (GB): Scott Foreman Company.

Hartati H, Amanah S, Sobari MP. 2005. Perilaku petambak dalam konservasi hutan mangrove di Desa Jayamukti Kabupaten Subang Provinsi Jawa Barat. Buletin Ekonomi Perikanan. 6(1): 13-36.

Manoppo CM. 2009. Faktor-Faktor Yang Berhubungan Dengan Partisipasi Wanita Tani Dalam Usahatani Kakao (kasus di Kecamatan Palolo

Kabupaten Donggala Provinsi Sulawesi Tengah). [tesis]. Bogor (ID):Institut Pertanian Bogor.

Mardikanto. 2009. Penyuluhan Pengembangan Pertanian. Surakarta (ID): Sebelas Maret University Pr. . 2009. Redefinisi dan Revitalitas Penyuluhan Pembangunan. Bogor (ID): IPB Press. . 1993. Penyuluhan Pembangunan Pertanian. Yogyakarta (ID): Sebelas Maret University Press.

Muljono P. 2007. Learning society, penyuluhan dan pembangunan bangsa. Jurnal Penyuluhan. 3(1): 52-62.

[PEMPROV]. Gubernur Aceh. 2008. Qanun aceh nomor 10 tahun 2008 tentang lembaga adat. Aceh (ID): Gubernur Aceh. 
[PEMPROV]. Gubernur Aceh. 2008. Qanun aceh nomor 9 tahun 2008 tentang pembinaan kehidupan adat dan adat istiadat. Aceh (ID): Gubernur Aceh.

[PEMPROV]. Gubernur Aceh. 2011. Qanun aceh nomor 4 tahun 2011 tentang irigasi. Aceh (ID): Gubernur Aceh.

Pertiwi PR, Saleh A. 2010. Persepsi petani tentang saluran komunikasi usahatani padi. Jurnal Komunikasi Pembangunan. 08(2): 47-61.

Pulungan R. 2008. Pengaruh Metode Penyuluhan Terhadap Peningkatan Pengetahuan Dan Sikap Dokter Kecil Dalam Pemberantasan Sarang Nyamuk Demam Berdarah (PSN-DBD) di Kecamatan Helvetia tahun 2007. [tesis]. Medan (ID): Sekolah Pasca Sarjana. Universitas Sumatera Utara.

Putra AWS, Hariadi SS, Subejo. 2016. Peran keujreun blang terhadap perilaku petani dalam pengelolaan air pertanian di Nanggroe Aceh Darussalam. prosiding seminar nasional multi disiplin ilmu \& call for papers unisbank (sendi_u) ke-2 tahun 2016. Program Studi Penyuluhan dan Komunikasi Pembangunan, Sekolah Pascasarjana, Yogyakarta (ID): Universitas Gadjah Mada. Tersedia pada: http://www.unisbank.ac.id/ojs/index.php/sendi_u/ article/view/4287/1291.

Sari N, Fatchiya A, Tjitropranoto P. 2016. Tingkat penerapan pengendalian hama terpadu (PHT) sayuran di Kenagarian Koto Tinggi Kabupaten Agam Sumatera Barat. Jurnal Penyuluhan. 12(1): 15-30.

Sari N. 2016. Penerapan pengendalian hama terpadu (PHT) sayuran di Kenagarian Koto Tinggi Kabupaten Agam Sumatera Barat. [tesis]. Bogor(ID): Institut Pertanian Bogor.

Sawerah S, Muljono P, Tjitropranoto P. 2016. Partisipasi masyarakat dalam pencegahan kebakaran lahan gambut di Kabupaten Mempawah Provinsi Kalimantan Barat. Jurnal penyuluhan. 12(1): 89102.

Saylor JG, Alexander WM. 1996. Curriculum Planning of Training. New York (US): Halt Reineheart \& Winston, Inc.

Soekartawi. 1988. Prinsip Dasar Manajemen Pemasaran Hasil Pertanian Teori dan Aplikasi. Jakarta (ID): Rajawali Press.

Suherdi. 2014. Motivasi petani dalam usaha hutan rakyat Desa Cingambul Kabupaten Majalengka. [tesis]. Bogor (ID): Institut Pertanian Bogor.
Sutiyah. 1990. Perempuan, Kerja dan Rumah Tangga. Yogjakarta (ID): Gadjah Mada University Pr.

TahituME.2015.PengembanganKapasitas Pengelolaan Sagu dalam Meningkatkan Pemanfaatan Sagu di Maluku Tengah Provinsi Maluku [d is erta si]. Bogor [ID]. Institut Pertanian Bogor.

Undang-undang. 2006. "Undang-undang Republik Indonesia Nomor 16 Tahun 2006 tentang Sistem Penyuluhan Pertanian, Perikanan dan

Kehutanan". Tersedia di http://www.deptan.go.id; Internet; diakses pada tanggal 11/09/2017.

Van den Ban AW, Hawkins HS. 1999. Penyuluhan Pertanian. Yogyakarta (ID): Kanisius.

Wiraatmadja. 1990. Pokok-pokok penyuluhan pertanian. Jakarta (ID):Yasaguna.Yulia, Sulaiman, Herinawati. 2012.Pemberdayaan fungsi wewenang keujreun blang di Kecamatan Sawang Aceh Utara. Jurnal Dinamika Hukum. 12(2): 369-378.

Yumi, Sumardjo, Gani DS, Sugihen BG. 2011. Model pengembangan pembelajaran petani dalam pengelolaan hutan rakyat lestari (Kasus di Kabupaten Gunung Kidul Provinsi Daerah Istimewa Yogyakarta dan Kabupaten Wonogiri Provinsi Jawa Tengah). Jurnal Penelitian Sosial dan Ekonomi Kehutanan. 8(3): 196-210. 